\title{
From Gaia to the Pythia
}

\author{
Prophecy Suits Women
}

\author{
Manuela Giordano (University of Calabria)
}

This paper explores the ambiguous connection between women and prophecy in ancient Greece. The issue of the genealogy of the prophetic seat of Delphi - the most authoritative oracle of ancient Greece - is first dealt with in relation to Aeschylus' Eumenides (458 B.C.E.), where the gift of prophecy is said to have been first endowed to Gaia, Mother Earth, to be passed on from mother to daughter until it is given to Apollo, the god of prophecy. Starting from this testimony, the role of Gaia is used in the paper as a key to understanding the motherly symbols associated with prophecy. The paper further explores how the powerful prophetic voice and role of the Pythia is "normalized" in the context of fifth century Athens, where women were not allowed to be public speakers or agents and where the dominant male voice constructed any public feminine voice as inappropriate or deviant. In this respect, the paper points out how in the Athenian representation of the Pythia, the authoritative heir of Gaia is reduced to a reconciling woman acting as a devout supporter of men and their authority.

Biblical prophecy stands out as a predominantly male business. ${ }^{1}$ The most authoritative prophetic voice of ancient Greece was the female voice of the Pythia, the celebrated and internationally renowned prophetess of Apollo, the god of prophecy, acting in the oracular seat of central Greece, Delphi. This prominence of a female character is all the more puzzling and interesting as in ancient Greek society women's voice and agency were severely restricted, repressed, and marginalized. ${ }^{2}$

In this article I explore the ambiguous connection between women and prophecy in ancient Greece through our earliest attestation of the role of the Pythia, Aeschylus' Eumenides (458 B.C.E.). The tragedy portrays the prophetess as speaking in the first person; she introduces herself as standing in a long line of prophetesses starting with the goddess Gaia, the Earth, here designated as the "first prophet." In this context I analyze the relevance of Gaia, a quintessential feminine divine figure, in relation to prophetic truth. In examining Greek texts I have chosen to address a somewhat limited timespan, from Homeric texts, corresponding to about the time of the Kingdom of Judah $\left(9^{\text {th }}\right.$ to $7^{\text {th }}$ centuries B.C.E.), to Aeschylus' time (525-458 B.C.E.), roughly corresponding to the period of Nehemiah. This allows me to address the issues at stake with a greater historical accuracy. In particular I have deemed it methodologically safer not to use the texts of Plutarch (46-120 C. E.), even if this au-

1 The four prophetesses of the biblical texts, Miriam, Deborah, Hulda and Noadiah, seem to fulfill men's role rather than having an agency of their own. See the other articles in this issue.

2 See infra. 
thor is our main source for Delphic divination and the Pythia, as this author writes in a completely different historical and cultural context. In my opinion, it is not warranted to assume, as scholars often do, that we can use Plutarch's witnesses to read Greek archaic and classical age realities. ${ }^{3}$

Before we turn to the Pythia it is imperative to set this prophetess in the proper framework of ancient Greek religious conception. To this end I will briefly recall some of the fundamental features that make up the ancient Greek religious picture. The generalizations that follow are valid as far as the fourth century B.C.E., and some of them are to a small extent overlapping with each other: (1) In ancient Greek there is no word for "religion" or "faith," indeed there is no such thing as "religion" as we understand it. ${ }^{4}$ (2) Our distinction between secular and religious, which is so central for our own social identity, was not held in ancient Greece, nor can we distinguish politics from religion..$^{5}(3)$ There are no sacred texts or corresponding fixed sets of beliefs. (4) There is no clergy, the priests being ritual operators, appointed sometimes on a temporary basis, with some exceptions. (5) There is neither orthodoxy nor orthopraxy, at least strictly speaking. (6) There is no idea of absolute or revealed truth (regarding either the gods or other ideas). (7) Greek gods, unlike the God of monotheistic traditions, did not create the world, and, following from it, they were not separate from the world, and particularly from the world of the polis. ${ }^{6}$

However little seems to be left of what we usually study and identify as religious features, the world the Greeks inhabited was perceived as full of sacredness and divine powers. To ancient Greek eyes, the world brimmed with the presence of gods, and life's uncertainties and adversities could be attributed to the uncanny ways of divine action. The absence of divine revelation or a

3 As a Platonist, furthermore, Plutarch is deeply influenced in his readings by the philosopher's understanding of divination, which, again, is a rather idiosyncratic view of the ancient facts. On Plutarch and Delphi, see D. Jaillard, "Plutarque et divination: la piété d'un prêtre philosophe," RHR (2007): 149-69.

4 On this, see M. Giordano, "As Socrates Shows, the Athenians Did Not Believe in Gods," Numen 52 (2005): 325-55.

5 As stated by Sourvinou-Inwood: "The polis was the institutional authority that structured the universe and the divine world in a religious system... the role of the polis in the articulation of Greek religion was matched by the role of religion in the articulation of the polis: religion provided the framework and the symbolic focus of the polis"; see C. Sourvinou-Inwood, "What is Polis Religion?" in The Greek City: From Homer to Alexander (eds. O. Murray and S. Price; Oxford: Oxford University Press, 1990), 295-322, 302; See also M. Giordano, "Out of Athens: Ritual Performances, Spaces, and the Emergence of Tragedy," in Submerged Literature in Ancient Greek Culture: An Introduction (eds. G. Colesanti and M. Giordano; Berlin: de Gruyter, 2014): 151-77, 151-57.

6 J.N. Bremmer, Greek Religion (Oxford: Oxford University Press, 1994), contrasts Greek gods with those of the Christian and Muslim traditions: "Unlike Christianity and Islam, Greek religion was polytheistic"; "Unlike God or Allah, polytheistic gods only cover a limited sphere of life" (ibid., 4); "Greek gods resembled and differed from the Christian God in important aspects. Like Him, they were invisible, but they were not loving, almighty, or omnipresent" (ibid., 11). 
set of doctrines (see above: points 3,5,6), rendered all the more important the role of those people who were endowed with the capacity to get in touch with truth and with the gods' will. Manifold methods arose for decoding the messages and signs that revealed the gods and their will. The complexity of these ancient practices is conventionally sorted out by distinguishing between "inspired prophecy" and "divination by signs."

Inspired prophecy is the capacity to communicate directly with the gods, by becoming the mouthpiece of a god, particularly of Apollo, mostly in a state of altered consciousness. Divination by signs, in contrast, is achieved by decoding different sets of signs in order to acquire divine knowledge about something. ${ }^{8}$ Both inspired prophecy and divination by signs are present in our earliest Greek texts, the Homeric poems, Iliad and Odyssey. They witness to a centuries-long oral and then written composition and transmission, which included different chronological materials and cultural phases. In the first book of the Iliad, Achilles calls the assembly of the Greek army to question the ritual specialists about the cause of the god-sent plague: "Let us ask some seer or priest, or some reader of dreams - for a dream too is from Zeus - who might say why Phoebus Apollo is so angry, whether he finds fault with a vow or a hecatomb."

Chalcas is the specialist with prophetic knowledge who will answer Achilles' question, and he is described as: "far the best of bird-diviners, who knew the things that were, and that were to be." ${ }^{10}$ In this passage we find mention of both ways of accessing truth on the same plan: divination by signs (and possibly extispicy, dream divination), as well as inspired prophecy. ${ }^{11}$

Oracles and prophecies were part and parcel of ancient Greek civic piety, and consulting oracles furthermore was considered the central act of euse-

7 See most recently Y. Ustinova, "Modes of Prophecy or Modern Arguments in Support of the Ancient Approach," Kernos 26 (2013): 25-44.

8 See on this point J.-P. Vernant, "Paroles et signes muets," in Divination et rationalité (ed. J.-P. Vernant; Paris: Maspero, 1974), 9-25; W. Burkert, "Signs, Commands, and Knowledge: Ancient Divination between Enigma and Epiphany," in Mantikê: Studies in Ancient Divination (eds. S. I. Johnston and P. Struck; Leiden: Brill, 2005), 29-49. The bibliography on divination is quite extensive, see Vernant, Divination et rationalité; A. Motte and V. Pirenne-Delforge, eds., Manteia: Pratiques et imaginaire de la divination grecque antique (Actes du XIII colloque international du CIERGA; Paris, Oct. 2011) = Kernos 26 (2013). For a comparative Near Eastern and Mediterranean perspective, see S. Georgoudi, R. Koch Piettre, F. Schmidt, eds., La Raison des signes: Présages, rites, destin dans les sociétés de la Méditerranée ancienne (Leiden: Brill, 2012); J. Stökl and C. L. Carvalho, eds., Prophets Male and Female: Gender and Prophecy in the Hebrew Bible, the Eastern Mediterranean, and the Ancient Near East (Atlanta: SBL, 2013).

9 Iliad, 1, 1l. 62-65, transl. by S. Butler, The Iliad of Homer (London: Longmans, Green, \& Co., 1898).

10 Iliad, 1, 1l. 70-71. I can only note in passing that in these lines the difference between inspired prophecy and divination by signs collapses: the power of "seeing" directly an invisible reality (inspired prophecy) is attributed to Chalcas as a bird-diviner (divination by signs).

11 See M. Giordano, Omero Iliade 1, la peste, l'ira (Rome: Carocci, 2010), 141-142. 
beia, of piety, together with sacrificing. The historian Xenophon (ca. 430-354 B.C.E.) was one of the major defenders of Socrates against the accusation of impiety (asebeia); in the Memorabilia, the author intends to prove that the philosopher was in fact a perfectly pious citizen and that the accusation of impiety was altogether unfounded. To demonstrate his point he argues:

What evidence did they dispose of in arguing that he didn't venerate the gods of the polis? In fact, he openly sacrificed at home, often on the common altars of the polis and he never hid the fact that he used divination. (Memorabilia, 1.1.2); ... as for his behavior towards the gods, it's patent that his actions and words were coherent with Pythia's responses on sacrifices, the cult of the ancestors or other similar matters. As a matter of fact, she responds that he who acts according to polis' custom is pious, and this is how Socrates acted and invited others to act (Memorabilia, 1.3.1). ${ }^{12}$

As the passage indicates, the simple fact of going to Delphi and listening to and following the Pythia's response was considered a proof of piety. The enormous influence and authority of the Pythia also stands out in the words of Xenophon: whatever she would say on the main acts of cult would be regarded as a sort of ipsa dixit. The role of Delphic consultation, and therefore of the Pythia herself, was central to Greek religious piety in general and paramount in divination and prophetic practices in particular. What interests us furthermore is that the oracular prophecies were uttered through the prophetic voice of a woman, Apollo's priestess. ${ }^{13}$

The small town of Delphi was the main oracular seat of ancient Greece and one of the most famous in the Eastern Mediterranean world of the first millennium. ${ }^{14}$ It suffices to say that in our sources the Pythia is consistently described - in a meaningful historical continuum - as the double of the god, endowed with the greatest authority. When the Pythia is said to speak, it is as if Apollo in person is speaking. ${ }^{15}$

As already mentioned, the prologue of Aeschylus' Eumenides is an especially valuable witness, as the earliest attestation of the Pythia's role, and even more so as the only passage in which the Pythia speaks in the first person. The priestess opens the tragedy with a prayer addressed to the deities that have ruled Delphi over time:

First, in this prayer of mine, I give the place of highest honor among the gods to the

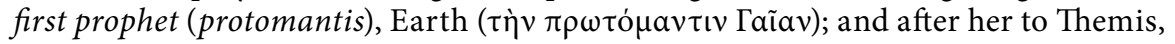

12 On the relevance of these statements in the context of Socrates' accusation, see M. Giordano, "As Socrates Shows, The Athenians Did Not Believe in Gods," Numen 52 (2005): $337 \mathrm{f}$.

13 On the question of Pythia's agency, see infra.

14 See H.W. Parke and E.E.W. Wormell, The Delphic Oracle (Oxford: Oxford University Press, 1956); G. Roux, Delphes: Son oracle et ses dieux (Paris: Les Belles Lettres, 1976); J. Fontenrose, The Delphic Oracle (Berkeley: University of California Press, 1978); S. Price, "Delphi and Divination," in Greek Religion and Society (eds. P. E. Easterling and J.V. Muir; Cambridge: Cambridge University Press, 1985), 128-44; G. Rougemont, "Loracle de Delphes: quelques mises au point," Kernos 26 (2013): 45-58.

15 Cf. e. g., Hdt. Hist. 5.63, 90; 6.66, 123; Thuc. 5.16; Plut. Lys. 25.3; Paus. 3.4.3. 
for she was the second to take this oracular seat of her mother, as legend tells ( $\dot{\omega} \varsigma$ $\lambda$ ó $о$ oৎ $\tau \iota \varsigma) .{ }^{16}$

In these first lines, Aeschylus reconstructs the "pre-history" of Delphic prophecy and reports an authoritative, ancient tradition, designated as logos (here, "myth," "legend," "story"; 1. 4). According to the mantic genealogy, the protomantis, the first prophet, was Gaia, the Earth; the second was Themis, her daughter. The term protomantis is very telling as a designation for Gaia, who was at the same time a goddess and the Earth itself; the ancient Greeks thought of Gaia as the mother and matrix of all living beings. As we will see, Gaia is more than the forerunner of the Pythia, she is also the primordial prophetess, inasmuch as she symbolizes the very source of prophetic truth. By evoking this primacy, Aeschylus momentarily seems to displace Apollo from his prophetic seat. Apollo is but a newcomer, while, from time immemorial, the goddess presiding over the oracle was Gaia, the Earth Mother.

\section{Gaia and Feminine Primacy: A Question of Method}

Stella Georgoudi has drawn our attention to the tendency to extend the role of protagonist to women and to the feminine element - in her words, a "feminine primacy" - on the oracular sites of Greece, and she expresses a strong caution against the method of "getting back to the matrix" when speaking of the "origins" of oracles: "pour des raisons qui tiendraient aussi - j'ose dire - à un vague besoin de 'retour à la matrice,' on cherche à remonter à la 'source originelle' qui ne saurait être que 'féminine."'17 Georgoudi's warning is important and reminds us to commit to a more historical approach to the question, disentangling the reflection on the various mentions of Gaia/Ge in oracular contexts from the temptation to apply an ahistorical model of the primordial Mother-Goddess over discrete realities in an evolutionistic fashion. Still the challenge has to be met, and we should come to terms with the fact that Aeschylus explicitly defines Gaia as the protomantis (Eum. 2), "primordial prophetess," seemingly fitting among the number of those who have placed a great oracle "sous le signe d'une divinité feminine chthonienne, Gaia ou Ge de préférence, à laquelle ils auraient à l'origine appartenu, avant de passer, par la force ou par la concession amicale, sous la domination d'un dieu." 18

16 Aeschylus, Eumenides, 1-4, translated by H. Weir Smyth, Agamemnon, Libation Bearers, Eumenides (Cambridge, MA: Harvard University Press 1960).

17 S. Georgoudi, "Le porte-parole des dieux: réflexions sur le personnel des oracles grecs," in Sibille e linguaggi oracolari: Mito storia tradizione. Atti del convegno, Macerata - Norcia Settembre 1994 (eds. I. Chirassi Colombo and T. Seppilli; Pisa-Roma: Istituti Editoriali e Poligrafici Internazionali, 1998), 315-65, 317. Roux, Delphes, 19, is among the scholars who have recognized in Gaia the primordial mantis. On the question of feminine primacy, see S. Georgoudi, "Bachofen, le matriarcat et le monde antique: Réflexions sur la création d'un mythe," in Histoire des femmes en Occident: vol. 1, L'Antiquité (eds. G. Duby and M. Perrot; Paris: Pion, 1991), 477-91; on goddesses and gender, see G. Pironti, "Des dieux et des déesses le genre en question dans la représentation du divine en Grèce ancienne," Mètis (2013): 155-67, $160 \mathrm{ff}$.

18 Georgoudi, "Le porte-parole des dieux," 317. I will do battle elsewhere with the much broader issue, somehow implied in the present discussion, of the many explicit connections 


\section{Life and Prophecy Come from the Earth}

Let us ask then, who was Gaia? And what was her relationship to prophetic truth? ${ }^{19}$

In Greek cosmology, gods are part and parcel of the world, which "is not created by an external god, as the priestly author of the biblical narration has it; it was born and gets differentiated to the point of forming other generations of beings that are at the same time cosmic (parts of the world) and supernatural (gods)." ${ }^{20}$ The Olympian gods, just like men, were ultimately created and born from Mother Earth to be the most powerful part of the kosmos; their power was consequently limited by their relative spheres of influence, which, with time, may overlap. ${ }^{21}$

In order to reconstruct the context in which Gaia belongs, we will mostly follow the narration of Hesiod's Theogony (ca. $7^{\text {th }}$ cen B.C. E.). This cosmogonic poem narrates the origins and formation of the world and the first divine genealogies, with the ensuing struggle for sovereignty until the establishment of Zeus' kingship. In the Theogony Hesiod attempts to create a taxonomy of powers, orders, and gods, to adjust to various successions of sovereignty, layers and stratification of powers and jurisdictions, where new divine generations overcome the older ones. ${ }^{22}$ Together with Homeric texts, moreover, the Theogony was considered a foundational text by the ancient Greeks themselves, as a famous quote from Herodotus (ca. 484-425 B.C. E.) clearly states:

But whence each of the gods came to be, or whether all had always been, and how they appeared in form, they did not know until yesterday or the day before, so to speak; for I suppose Hesiod and Homer flourished not more than four hundred years earlier than I; and these are the ones who taught the Greeks the descent of the gods, and gave the gods their names, and determined their spheres and functions, and described their outward form. [3] But the poets who are said to have been earlier than these men were, in my opinion, later. The earlier part of all this is what the priestesses of Dodona tell; the later, that which concerns Hesiod and Homer, is what I myself say. ${ }^{23}$

in our sources between women and prophecy in general. On Greek prophetesses see A.C. Hagedorn, "The Role of the Female Seer/Prophet in Ancient Greece," in Prophets Male and Female, 101-26.

19 On the connection of Gaia to Delphi, see C. Sourvinou-Inwood, "Reading” Greek Culture (Oxford: Oxford University Press, 1991), 217-43; and F. Quantin, "Gaia oraculaire: tradition et réalités," Mètis 7 (1992): 177-99.

20 P. Borgeaud and T. Römer, "Mythologie de la Méditerranée et du Proche Orient: regards croisés sur l'origine de l'humanité," in Religions antiques: Une introduction comparée (eds. P. Borgeaud and F. Prescendi; Geneva: Labor et Fides, 2008), 121-48, 125. On this point, see also Bremmer, Greek Religion, 4-6.

21 On Greek polytheism, see, for example, Bremmer, Greek Religion; S. Price Religions of the Ancient Greeks (Cambridge: Cambridge University Press, 1999); J.-P. Vernant, L'Univers, les dieux, les hommes: récits des origines (Paris: Le Seuil, 1999).

22 On Greek cosmogonies, see R. Sorel, Les cosmogonies grecques (Paris: PUF, 1994).

23 Herodotus, Histories, 2. 53, translated by A. D. Godley (Cambridge, MA: Harvard University Press, 1920). 
The Theogony sets Gaia, the Earth, at the very beginning of the cosmos, emerging straight after Chaos, the first cosmic entity, and she begins the line of engendered beings, whence the whole cosmos develops: "In truth at first Chaos came to be / But next wide-bosomed Earth, the ever-sure foundation of all."24

In what follows, Hesiod explains that Gaia by herself engendered the Sky, Ouranos, the Mountains, and the Sea; with Ouranos she beget the Ocean and the first generation of gods, the Titans, among them Themis ("Justice"), Mnemosyne ("Memory"), and Phoebe. From Rhea and Cronos - both Titans - the first generation of Olympian gods would then be created.

Gaia with her vast bosom is the mother, in the dual sense of first generator and absolute beginning of things, and she remains so in Theogony's narration, even with all the transformations that occur in later generations. Moreover, the motherhood of the Earth appears as a constant trait throughout our sources. ${ }^{25}$ From the cosmological point of view, this matrix is a real place, encompassing the Earth with the underground, ${ }^{26}$ Tartarus and Hades.

And there, all in their order, are the sources and ends of gloomy earth and misty Tartarus and the unfruitful sea and starry heaven, loathsome and dank, which even the gods abhor ( $\tau \dot{\alpha} \tau \varepsilon \sigma \tau u \gamma \varepsilon \dot{\varepsilon} 0 v \sigma \mathrm{l} 9 \varepsilon \circ i \operatorname{\pi \varepsilon \rho }$ ). [740] It is a great gulf, and if once a man were within the gates, he would not reach the floor until a whole year had reached its end, but cruel blast upon blast would carry him this way and that. And this marvel is awful

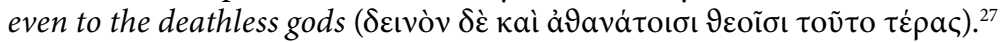

The origin, the roots, the source, the end of all components of the cosmos, sea, sky, and earth, is the vast opening underneath the Earth, a place and a power that baffle the gods $(11.739,743)$. This order founds and roots the world (1. 738); it acts as a perennial matrix, a beginning and therefore as a source of truth, where past, present, and future are connected in the chthonic dimension.

If Jewish and Christian cosmologies connect truth to the upper region of the world, contrariwise, the cosmological taxonomy of archaic and classical Greece

24 Hesiod, Theogony, 116-117, translated by H. G. Evelyn-White (Cambridge, MA: Harvard University Press, 1914).

25 See for example Pindar, Nemean Ode 6, 1-2 'There is one race of men, one race of gods; and from a single mother we both draw our breath.' For the cosmic motherly role of Gaia cf. also Euripides, Melanippe, fragment 5, and Chrysippe, fragment 6, in F. Jouan and H. Van Looy, Euripide. Fragments, lère. Partie (Paris: Budé, 1998) where the earth and the sky are the primordial couple engendering all the world and Gaia is said "the mother (meter) of all things." In Dodona too we hear of memories of Gaia. Pausanias 10.12.10, reports that the priestesses of the god sing two hexameters, the first being "Zeus is, Zeus shall be, o mighty Zeus," while the second says, "Gaia sends up the harvest; therefore glorify the Gaia as Mother." Dodona too then testifies to a recurrent connection between Mother Earth, the oracular word, and Zeus, as well as the role of priestesses in taking care of and interpreting the oracular voice. On the oracle of Dodona, see most recently S. Georgoudi, "Des sons, des signes et des paroles la divination à l'œuvre dans l'oracle de Dodone," in La Raison des signes, 55-90.

26 See Quantin, “Gaia oraculaire," $184 \mathrm{f}$.

27 Hesiod, Theogony 736-741, translated by H. G. Evelyn-White (Cambridge, MA: Harvard University Press, 1914). 
- up until Plato - locates the seat of "truth" below the earth instead..$^{28}$ On the theogonic level the earth and the underground - the order of Gaia - stand as a primum in relation to the Olympian gods: as the abode of the first divine generation, the Titans and primordial beings, they are endowed with a primordial value in time and in power, over which the Olympian gods have neither power nor jurisdiction, and to which, in a way, they have to submit. Even when Olympian primacy is established, knowledge, wisdom, and truth keep dwelling where all things and all beings first sprouted, as the oath of the gods demonstrates. ${ }^{29}$

The identity of Gaia as "mother of all things" remains prominent throughout the classical age, where her role as "giver and receiver of plant and animal life" becomes prominent. ${ }^{30}$ In a passage of the Libation Bearers, prayers are addressed to Hermes chthonios (of the Netherworld) and to, "Earth herself, who gives birth to all things, and having nurtured them receives their increase in turn." 31

The underground as Netherworld is, in addition, the place of the dead, the space of Hades, which is singled out in some archaic texts as the center and material root of the universe, the dwelling-place of absolute truth. ${ }^{32}$ The dead themselves are a source of prophecy and, with prophetic dreams, belong to the realm of Gaia. In Aeschylus' Persians (472 B.C.E.), for instance, dreams, the dead, and Gaia are united in an act of cult when the Persian Queen Atossa tells the Chorus of elderly Persian counselors of a dream full of foreboding regarding the defeat of her son Xerxes by the hands of the Greeks, and the Chorus suggests that she should offer libations to Earth and the dead (Aeschylus, Persians, 220).

The oracular prominence of the so-called craters is all the more relevant: in ritual Greek geography there were hollows, openings in the ground, chasms, which permitted contact with the underground. ${ }^{33}$ These craters were represented as passages to the descent into the Underworld, privileged places for

28 In Parmenides' poem On the nature of things, the philosopher tells of his journey on a chariot that leads him beyond the door of day and night, into the realm of infinite chaos (chasma achanes), where he finds a goddess (probably Persephone) who reveals the truth to him (fr. D. K. 1). See G. Cerri, Parmenide di Elea, Poema sulla natura (Milan: Rizzoli, 1999), ad loc. Plato will place truth in the hyperuranium, while Aristotle will give this cosmological inversion the systematic codification that will pass on to Christian authors. See also Y. Ustinova, Caves and Ancient Greek Mind: Descending Underground in the Search for Ultimate Truth (Oxford: Oxford University Press, 2009), for the relevance of the Netherworld to ultimate truth.

29 The Olympian gods swear by Styx, the goddess and primordial water set in the depth of the underground; for a discussion, see M. Giordano, La parola efficace: Maledizioni, benedizioni e giuramenti nella Grecia antica (Pisa-Roma: Istituti Poligrafici Internazionali, 1999), 38-39.

30 J.D. Mikalson, Honor Thy Gods: Popular Religion in Greek Tragedy (Chapel Hill: University of North Carolina Press, 1991), 55.

31 Aeschylus, Libation Bearers, 126-127, translated by H. Weir Smyth, Agamemnon, Libation Bearers, Eumenides (Cambridge, MA: Harvard University Press 1960).

32 See G. Cerri, "Cosmologia dell'Ade in Omero, Esiodo e Parmenide," Parola del Passato 50 (1995): 437-67.

33 P. Kingsley, Ancient Philosophy, Mystery, and Magic: Empedocles and Pythagorean Tradition (Oxford: Oxford University Press, 1995), 133-34. 
oracles, ordeals, divinatory dreams and, oaths: that is to say, for those practices that requested contact with the "truth." These practices and narratives unveil a consistent symbolic association of the Earth with the original location of truth, insofar as she is the genesis and end of all things living. ${ }^{34}$ In mythical encoding, Gaia is an encompassing dominion of the cosmos where these several sources and places of truth are strongly interconnected, if not also theorized in an orderly fashion.

\section{Delphic Resonances}

The ancient power of Gaia over Delphi - not merely as a first prophetess in the timeline but in fact as an ongoing presence - is embedded in the symbols and stories surrounding the sanctuary. We might see this, first, in the understanding of contact with the earth as a source of divination. The Delphic accounts report that the Pythia sat on her tripod in the adyton of the temple, the inner chamber, where a vapor issued forth from a crack in the ground, imbuing the Pythia with prophetic capacity. This claim is not actually attested in our earlier texts. Its mention in later authors seems all the more significant as support for the permanence of the idea of a connection between prophetic powers and contact with the earth and the underground. Diodorus Siculus, the historian of the first century B.C.E., connects the origin of the oracle with a goatherd's discovery that this hole in the ground gave off fumes that provoked a state of mantic possession in whoever inhaled them, goats and goatherd alike. Diodorus continues that, "in time, as many people leaped down the hole because of their state of possession and all disappeared, the locals, to eliminate the danger, appointed one woman as prophetess for all, through whom the giving of the oracles was to take place" (16.26). The opening in the ground, much like the craters mentioned above, can be interpreted as a means to establish a direct connection with the realm of aletheia underground..$^{35}$

Scholars were taken aback when archaeological surveys did not reveal any type of opening in the sanctuary at Delphi, concluding that representations of this chasm must have been symbolic. ${ }^{36}$ Indeed, the absence of any such element highlights the significance of the symbolic association of the oracular power as coming from the Earth.

The oracle furthermore was thought of as connected to motherhood and birth, firstly by its name: the word Delphoi is etymologically connected to del-

34 Despite the title, L. Couloubaritsis, "L'art divinatoire et la question de la vérité," Kernos 3 (1990): 113-22, does not touch upon the question of prophetic truth as such; it is, rather, a diachronic survey of texts dealing with the truthfulness of oracles from Homer to Plutarch.

35 See M. Detienne, Les maîtres de vérité dans la Grèce archä̈que (Paris: Maspero, 1967), passim.

36 See S. Price, "Delphi and Divination" Pages 128-144 in Greek Religion and Society (Edited by P.E. Easterling and J.V. Muir. Cambridge: Cambridge University Press 1995), 140. 
phys, the womb, and thus to the symbolic matrix of the world, Gaia, and to her motherly associations. In the second place, Delphi was thought as the Navel - the center - of the world; according to a famous narrative, Zeus sent two eagles, one from the East and the other from the West, and they met precisely at Delphi. ${ }^{37}$ In the rear wall of the temple, protected by a stone canopy, was the omphalos, a stone Nombril venerated as the physical matrix from which the entire world originated. An omphalos - an egg-shaped stone - was actually unearthed in the innermost part of the temple. ${ }^{38}$ As Maurizio has it, "birthing imagery erupts in the content of oracles," giving birth is "the dominant metaphor in the divinatory ritual and in oracular pronouncements." ${ }^{39}$ These elements may allow us to submit that Aeschylus did not innovate in connecting Delphi to Gaia as first mantis, but transposed in a vertical lineage a link that was ever present in Delphic practices and symbols. ${ }^{40}$

\section{From Gaia to Apollo}

And in the third allotment, with Themis' consent and not by force, [5] another Titan, child of Earth, Phoebe, took her seat here. She gave it as a birthday gift to Phoebus, who has his name from Phoebe... Zeus inspired his heart with prophetic skill and established him as the fourth prophet on this throne; but Loxias is the spokesman of Zeus, his father. ${ }^{41}$

The first order of the cosmos - symbolized by Gaia and the first generation of the gods, who were not altogether overcome or vanquished - remains in the depth of the underground and creates a sort of tension between this matrix and the Olympian order, which is quite evident in relation to Delphi. The second and third prophets named in the Eumenides' prologue are Themis and Phoebe, both Titan daughters of Gaia. They already represent a transition to the following generation, hinting at the time when Olympian gods will defeat the Titans. The passage from one divine generation to the next is represented either as an act of violence or as a marriage. Themis, the second prophetess of the prologue, is also the second wife of Zeus: ${ }^{42}$

$37 \quad$ Strabo 9.3.6.

38 See H.W. Parke, A History of the Delphic Oracle (Oxford: Blackwell, 1939), plates 2, 9.

39 L. Maurizio, "The Voice at the Center of the World: The Pythia's Ambiguity and Authority," in Make Silence Speak: Women's Voices in Greek Literature and Society (eds. A. Lardinois and L. McLure; Princeton: Princeton University Press, 2001), 38-54, 49. See also M. Rigoglioso, The Cult of Divine Birth in Ancient Greece (Palgrave Macmillan: New York, 2009), 182-86.

40 Pace Quantin, "Gaia oraculaire," who sees the oracular power of the Earth as an Athenian innovation.

41 Aeschylus, Eumenides, 4-8; 17-19, translated by H. Weir Smyth, Agamemnon, Libation Bearers, Eumenides (Cambridge, MA: Harvard University Press 1960).

42 See, on this theme, C. Miralles, "Le spose di Zeus e l'ordine del mondo nella 'Teogonia' di Esiodo," in Maschile/Femminile: Genere e ruoli nella culture antiche (ed. M. Bettini; Roma-Bari: Laterza, 1993), 17-44. 
Next he married bright Themis who bore the Horae, and Eunomia (Order), Dikë (Justice), and blooming Eirene (Peace), who mind the works of mortal men, and the Moerae (Fates) to whom wise Zeus gave the greatest honor, [905]. ${ }^{43}$

Zeus represents the new generation and the new order, which integrates the old one by marrying Themis; this is the rightful order of things (generating the Moerai, the Fates, which rule over destiny and the course of events). ${ }^{44}$ But the older generation is not written off: Themis stands in for Gaia, as mother and daughter are represented as the self-same goddess: ${ }^{45}$ "Often my mother Themis, or Earth (though one form, she had many names), had foretold to me the way in which the future was fated to come to pass." Likewise Phoebe, daughter of the Earth, seems to act as a reduplication of Gaia and emphasizes the character of willingness and of exclusion of violence from the prophetic succession over Delphi. She bestows the gift of prophecy to Apollo as a birthday gift and the god somehow absorbs the power of prophecy by taking his name, Phoebus, from this Titan daughter of the Earth.

In the narration of Hesiod's Theogony, Zeus gains sovereignty and comes to rule as king. He is superimposed in a second role, as well, as god of prophecy, thus appropriating many of the prerogatives and spheres originally attached to the primeval order that sits in the Earth. Included among these roles is not only prophecy but also Justice, which is strictly connected for the ancient Greeks with the oracular domain. ${ }^{46}$ It is interesting that in Aeschylus' Eumenides, Phoebe gives Apollo the gift of prophecy, but then Zeus reduplicates the action and bestows this gift upon his son (1. 17).

Now we are in a better position to understand the stratigraphy of meanings and narratives co-existing with Aeschylus' account of the words of the Pythia and in relation to which this passage should be read. The succession connecting the Pythia to Gaia in a single prophetic line is in fact the result of a stratification of epochs and traditions, which, however, are united in the female figure of the Pythia, redolent of a different, motherly past and present. The connection between the Earth and prophetic knowledge is firmly established in the cultural memory of the ancient Greeks, as is the fact that this knowledge has an eminently feminine and maternal connotation. We should reiterate that this argument does not point to an "origin" for the sanctuary so much as to the here and now of ritual practice. For the Greeks of, say, the fifth century, Pythia's capability came from the contact with the underground in every here and now of any given consultation. Pythia's inspiration is connected to the cosmological network of Gaia - and has close to nothing in com-

43 Aeschylus, Prometheus, 211-213, translated by H. Weir Smyth, Prometheus, Suppliant Maidens, Seven agaiinst Thebes (Cambridge, MA: Harvard University Press 2006).

44 Hesiod, Theogony, 901-904, translated by H. G. Evelyn-White (Cambridge, MA: Harvard University Press, 1914). Miralles, "Le spose di Zeus," 27-29.

45 On Themis and Moirae, see G. Pironti, "Dans l'entourage de Thémis: les Moires et les 'normes' panthéoniques," Kernos, Supp. 21 (2009): 13-27.

46 See Detienne, Les maîtres de vérité, 17-33. 
mon with Apollo's configurations. The result is a double channel of prophetic inspiration, one from Gaia and another from Apollo. ${ }^{47}$

We should note, as well, that Athenians thought of themselves as being born of the Earth, authochtonoi. They "claimed with pride that their ancestors had always lived in Attica... Related to this Athenian belief that they had always lived in Attica, was a second that, as a people, they were literally 'sprung from the earth."'48 Athenian mythical semantics further enrich the identity of Gaia by incorporating a local myth; the Gaia that Aeschylus describes is a Panhellenic Hesiodic configuration of this goddess, combined with another local connotation of the Gaia-Earth, closer to the heart of the Athenians and in this respect even more authoritative and influential. ${ }^{49}$

\section{Aeschylus' Pythia: An Athenian Portrait of a Prophetess}

In historical Athens, to be active and participate in public and political life meant first and foremost participation in parrhesia, free speech, along with permission to speak in the public venues conceived toward this end: tribunals, Assembly, theatre, Council. Women were never allowed to be public speakers, and they could not in any way share political agency, which was by definition a masculine domain. ${ }^{50}$ As I have shown elsewhere, the dominant male voice would construct any public feminine voice as inappropriate or deviant. Even when allowed to speak, a woman's voice would comply with men's requirements and agendas. ${ }^{51}$

The Pythia - endowed with powers issuing from the underground and imbued with Apollonian inspiration - was a powerful woman, probably the most powerful woman in all of ancient Greek history. The powerfully authoritative voice of the Delphic prophetess seems to stand at odds with the role men assigned to women, at least by fifth century Athenian standards, and in sharp contrast or paradoxical relationship with their social orientation. ${ }^{52}$

47 See below.

48 V.J. Rosivach, "Autochtony and the Athenians," CQ 37 (1987): 294-306, 294. See also N. Loraux, The Children of Athena: Athenian Ideas about Citizenship and the Division of Sexes (Princeton: Princeton University Press, 1993; orig. publ. Paris, 1981); idem, Born of the Earth: Myth and Politics in Athens (Cornell: Cornell University Press, 2000; orig. publ. Paris, 1996).

49 See on this connection F. Quantin, 1992. "Gaia oraculaire: tradition et réalités", Mètis 7 (1992): 177-199. For Gaia cults in Athens, see L. R. Farnell, The Cults of the Greek States (5 vols.; Oxford: Oxford University Press, 1896-1909), 3.308-9.

50 On the many aspects of the voice of women see G. Holst-Warhaft, Dangerous Voices: Women's Laments and Greek Literature (London and New York: Routledge, 1992); L. McClure, Spoken Like a Woman: Speech and Gender in Athenian Drama (Princeton: Princeton University Press, 1999); Lardinois and McLure, Make Silence Speak.

51 See M. Giordano, "Ritual appropriateness in the Seven Against Thebes: Civic Religion in a Time of War," Mnemosyne 59 (2006): 52-74; and M. Giordano, "Women's Voice and Religious Utterances in Ancient Greece," Religions 2 (2011): 729-43.

52 On the topics of the role of priestesses and power see L. Bruit, "La pretrêsse et le roi: Réflexions sur le rapport entre la prêtrise féminine et le pouvoir," Mètis (2013): 87-100; on 
The markedly feminine quality of the Delphi oracle has raised some questions within modern scholarly debate. Until the 1970s most scholars argued, with varying overtones, that the actual agents of Delphi were not the Pythia but the priests who worked in the sanctuary. These prophetai held power that allowed them to manipulate the priestess and her responses. ${ }^{53}$ Price was the first to demonstrate that this contention was unfounded, and Maurizio, following up on this insight, states that, "not one ancient source suggests that anyone other than the Pythia issued oracular responses." ${ }^{4}$ In other words, there is no doubt in our sources as to the agency of the Pythia in the Delphic oracle. ${ }^{55}$ The question of how modern scholarship has reaffirmed the male agency dislocated by Delphic practices, in contrast, remains a topic for another day.

Despite the full female agency at Delphi, Aeschylus in his Eumenides manages to draw a portrait of the Pythia with typically Athenian feminine connotations. Her free-speaking Delphic voice is bridled in the tragedy by a frame of semiotic references that transform her into a familiar Athenian woman, glossing over all elements of tension in her description.

At least three semiotic elements stand out in this treatment. The first is given by proxemics. In Athens, women were barred from public spaces. Their milieu was the interior, as is eminently expressed in Aeschylus' Seven against Thebes, when king Eteocles confronts the chorus of women who are panicstricken by the imminent siege of the enemy: "It is for the man to take care of business outside the house; let no woman make decrees in those matters. Keep inside and do no harm!" ${ }^{77}$ And furthermore, "It is the man's duty to offer victims and sacrifices to the gods when they test their enemy; your duty is to be silent and to remain inside the house." 58

However central her words for the management of Athenian and Greek international and domestic affairs, the Pythia as represented by Aeschylus stays inside the house, the house of Apollo. The word domos is used throughout the Oresteia - the tragic trilogy including Agamemnon, Libation Bearers, Eumenides - to indicate the temple. More specifically, the Pythia's place is in the hidden area called mychos, "recess," an "inside" that recalls the invisible and

priestesses see J.B. Connelly, Portrait of a Priestess: Women and Ritual in Ancient Greece (Princeton: Princeton University Press, 2007).

53 For a discussion of the term prophetai in relation to Delphi see Georgoudi, "Le porte-parole des dieux," $355 \mathrm{ff}$.

54 L. Maurizio, “Anthropology and Spirit Possession: A Reconsideration of the Pythia's Role at Delphi," The Journal of Hellenic Studies 115 (1995): 69-86, 69.

55 See Price, "Delphi and Divination," 141; and Maurizio, "Anthropology and Spirit Possession," part. 69-72. See most recently C. Pisano, "La voce della Pizia: tra mito, rito e antropologia," I Quaderni del Ramo d'Oro 6 (2013): 8-20.

56 See on these aspects of the Seven, Giordano, "Ritual appropriateness in the Seven Against Thebes."

57 Aeschylus, Seven against Thebes, 200-201, translated by H. Weir Smyth, Prometheus, Suppliant Maidens, Seven against Thebes (Cambridge, MA: Harvard University Press 2006).

58 Aeschylus, Seven against Thebes, 230-232. 
protected part of the women's quarters in the house and, as has been noted by Maurizio, also has a general connotation of an inner recess, body, earth, temple, "whence prophecy and poetry were believed to come." ${ }^{59}$ Athenian narrative has thus relocated this woman's exceptional power back into an ordinary cultural proxemics of gender opposition, male-female, outside-inside.

The second element in this treatment is sexuality. The continual struggle for control of women paired with control over their sexuality. The prophecies uttered by the Pythia are often encoded as offspring of her sexual union with Apollo, bestowing on the Pythia the trait of wife and mother, in tune with the role and image of the woman in her relationship with men. A counter-example with telling significance is found in the story of Cassandra, a frustrated prophetic voice. The warping of her prophetic gift seems to stand in relation to her untamed female character and her refusal of sexual union with Apollo. Having deceived Apollo and rejected marriage, she is punished by uttering prophecies that are met with disbelief. The fact that the Oresteia presents us with two prophetic women is quite telling, as the Cassandra of the Agamemnon is represented for the first time in our sources as a failed prophetess; at the same time she appears as the thwarted model of a bride-to-be, who rebels against her role. The Pythia of the Eumenides on the other hand, is an obedient woman whose words are given a primordial authority.

The third semiotic element in this treatment is normalization. The Homeric Hymn to Apollo $355 \mathrm{ff}$. tells how the god Apollo arrived in Delphi after many wanderings, slew the She-dragon, thereafter called Python - in a rather muddled account, to be honest - and installed himself on the oracular seat, where the Pythia was appointed as his priestess. ${ }^{60}$ The epic version keeps the memory of a struggle and a tension between the previous Delphic order guarded by the She-dragon and the new one, brought about by violence at the hands of the archetypically young god Apollo. An even more explicit account is given in Euripides' tragedy Iphigenia in Tauris (ca. 414 B.C. E.). Euripides tells how the infant Apollo killed the serpent guarding the prophetic seat in Delphi (11. 1251-1257) - and apparently held by Themis - and how the Earth revolted against this violence:

But when he came and sent Themis, the child of Earth, away from the holy oracle of Pytho, Earth gave birth to dream visions of the night; and they told to the cities of men the present, and what will happen in the future, through dark beds of sleep on the ground; and so Earth took the office of prophecy away from Phoebus, in envy, because of her daughter. The lord made his swift way to Olympus and wound his baby hands around the throne of Zeus, to take the wrath of the earth goddess from the Pythian home. Zeus smiled, that the child so quickly came to ask for worship that pays in gold. He shook his locks of hair, to put an end to the night voices, and took away from mortals the truth

59 Maurizio, "The Voice at the Center of the World," 47.

60 I cannot agree on this point with Quantin, "Gaia oraculaire" who sees no original conflict between Gaia and Apollo in the account and attributes it rather to Aeschylus' implicit interpretation of the account. 
that appears in darkness, and gave the privilege back again to Loxias, and to mortals confidence in the songs of prophecy at the throne visited by many men. ${ }^{61}$

The passage highlights the struggle over the privilege of oracular truth. The powerful feminine deities Themis and Gaia battle against the masculine supremacy of Apollo and Zeus; the clash, again, reflects tensions between old and new. It is interesting that unlike Aeschylus, Euripides represents a battling and wrathful Earth that has the power to strip the gift of prophecy from Apollo and from Delphi itself, defending the matrilineal genealogy of oracular truth. Zeus hands the privilege back to Apollo, but he is not said to confront Gaia directly; Zeus' intervention does not negate the strength of this goddess, nor does it eliminate the competition over prophetic authority.

On the contrary, Eumenides' Pythia celebrates how the prophets followed each other on the Delphic seat with a peaceful succession, glossing over all violence and constriction that the Homeric Hymn to Apollo and Iphigenia in Tauris report as a major feat of Apollo's biography.

The Aeschylean portrait of a collaborating Gaia (and Pythia), in other words, provides a normalized and reconciled version of the passage, where the new prophets smoothly succeed the older, of their own accord. The gap between the old and the new, and the arrival of Apollo, is no longer marked by violence and tension: what brings the prophetic line of Gaia to an end is not a conflict or Apollo's murderous actions, it is a birthday gift, from Phoebe to Phoebus. Athenian Aeschylus has thus reduced the Pythia from the mighty and authoritative heir of Gaia to a reconciling woman, a sort of elderly wife of Apollo, and in the process has served to "tame" the dangerous voice of a powerful woman, transforming her instead into a devout supporter of men folk and their authority.

61 Euripides, Iphigenia in Tauris, 1259-1282, translated by R. Potter (Iphigenia in Tauris, Adelaide: University of Adelaide Press 2014). 